\title{
Organic Inputs and Chemical Fertilizer on Carbon Mineralization From Two Ultisols
}

\author{
Daniel M. Kalala ${ }^{1}$, Victor Shitumbanuma ${ }^{1}$, Noah Adamtey ${ }^{2} \&$ Benson H. Chishala $^{1}$ \\ ${ }^{1}$ University of Zambia, Great East Road Campus, Lusaka, Zambia \\ ${ }^{2}$ Research Institute of Organic Agriculture (FiBL), Frick, Switzerland \\ Correspondence: Daniel M. Kalala, School of Agricultural Sciences, Soil Science Department, University of \\ Zambia, Great East Road Campus, P.O. Box 32379, Lusaka, Zambia. Tel: 260-977-749-368. E-mail: \\ danielkalala2@gmail.com
}

Received: July 13, 2020

Accepted: September 23, 2020

Online Published: October 15, 2020

doi:10.5539/jas.v12n11p223

URL: https://doi.org/10.5539/jas.v12n11p223

\begin{abstract}
There are challenges that limit the use of organic inputs for soil fertility management. Amongst them is the limited knowledge of factors that affect rates of decomposition and nutrient release from different organic inputs. A study was conducted on surface soil samples of two Ultisols to determine factors affecting carbon (C) mineralization from selected organic inputs. A loamy sand (LS) from a Kandiustult and a sandy clay loam (SCL) from a Paleustult were used. Fine earth fractions of the soils mixed with organic inputs with and without chemical fertilizer were incubated for 13 weeks and the $\mathrm{CO}_{2}$ evolved was measured. Organic inputs used were biomasses of Cajanus cajan, Tephrosia vogelii, Crotalaria juncea, Mucuna pruriens, a mixture of native grasses and shrubs and composted cattle manure. The latter two inputs are traditionally used by farmers, while the leguminous plants were recommended by scientists. Treatments with chemical fertilizer only, representing the conventional farming practice, and a control with soil alone were included. Addition of organic inputs with or without fertilizer increased total $\mathrm{CO}_{2}$ emissions by 81 to $129 \%$ on the LS and by 18 to $34 \%$ on the SCL. Adding chemical fertilizer significantly $(\mathrm{p}<0.05)$ increased $\mathrm{C}$ mineralization rate constant $(\mathrm{k})$ by $116 \%$ on the LS and $48 \%$ on the SCL. The mean residence time of organic carbon from treatments grouped by input type followed the order: Control $>$ Traditional $>$ Legumes $>$ Conventional on both soils. In general, the $\mathrm{k}$ on the LS was double that on the SCL. The type of organic input, soil texture and application of chemical fertilizer significantly affected $\mathrm{C}$ mineralization rates from the soils.
\end{abstract}

Keywords: carbon mineralization, chemical fertilizer, soil texture, mineralization rate constant $(\mathrm{k})$, mean residence time (MRT)

\section{Introduction}

Low soil fertility is one of the major constraints to achieving high crop yields, food security, and alleviating poverty in Sub-Saharan Africa (Ajayi, Akinnifesi, Sileshi, \& Chakeredza, 2007; Bindraban, Batjes, Leenars, \& Bai, 2010; Place, Barrett, Freeman, Ramisch, \& Vanlauwe, 2003; Rusinamhodzi, Corbeels, Zingore, Nyamangara, \& Giller, 2013). Although conventional farming systems that rely heavily on the use chemical fertilizers have been proposed as a solution to the low soil fertility (Matson, Parton, Power, \& Swift, 1997), there are a number of concerns on the suitability of such systems. This is in view of the challenge of balancing the requirement for increased food production with preserving the natural resource base, and coping with threats of climate change (Diacono \& Montemuro, 2010; Tilman, Cassman, Matson, Naylor, \& Polasky, 2002). The conventional farming systems have further been deemed to be unsuitable for most low-income small-scale farmers in Africa because of the high cost and sometimes unavailability of chemical inputs (Bationo et al., 2012; Lal, 1987).

The use of organic inputs with or without chemical fertilizer has been proposed as an alternative way of managing problems of low soil fertility in sub-Saharan Africa (Ajayi et al., 2007; Nalivata et al., 2017; Roobroeck, Van Asten, Jama, Harawa, \& Vanlauwe, 2015; Samuel \& Ebenezer, 2014). Although there is abundant literature citing benefits of using organic inputs alone or in combination with chemical fertilizer on soil fertility (Bouajila \& Sanaa, 2011; Diacono \& Montemuro, 2010; Muyayabantu, Kadiata, \& Nkongolo, 2013; Nyamangara, Piha, \& Giller, 2003; Waswa, Mugendi, Vanlauwe, Nandwa, \& Kung'u, 2003), there are still 
challenges with the use of organic inputs. They include how to determine correct application rates and when to apply the inputs to ensure that nutrient release coincides with crop nutrient demand. The challenges are largely due to differences in the nutrient mineralization rates of organic inputs (Nyamangara, Mtambanengwe, \& Musvoto, 2009) which are influenced by soil microbial activity, which in turn depends on the soil temperature, moisture content, $\mathrm{pH}$, and the quality of organic matter (E. Ambrosano, Trivelin, Cantarella, G. Ambrosano, \& Muraoka, 2003; Rustad et al., 2000).

As opposed to the readily release of nutrients to crops when chemical fertilizers are applied alone, the rate and pattern of nutrient release when fertilizer is applied with organic inputs varies widely (Khalafalla \& Hamed, 2015), depending on the $\mathrm{C} / \mathrm{N}$ ratio, lignin, and polyphenol contents of the organic inputs (Hossain et al., 2017; Khalafalla \& Hamed, 2015). Harmonizing nutrient release from organic inputs with crop nutrient requirements is critical to increasing crop yields and improving soil fertility in systems dependent on organic inputs for maintaining soil fertility. The objective of this study was to assess the effects of organic inputs, soil texture and application of chemical fertilizer on carbon mineralization. The hypothesis was that the rate of carbon mineralization in soils is significantly influenced by soil texture, type of organic inputs and addition of chemical fertilizer.

\section{Materials and Methods}

\subsection{Description of Sites From Which Soil Samples Used in the Study Were Obtained}

Surface soil samples from 0 to $20 \mathrm{~cm}$ depth were collected from field crop trial plots at Misamfu $\left(10^{\circ} 10^{\prime} 09.36^{\prime \prime}\right.$ S;

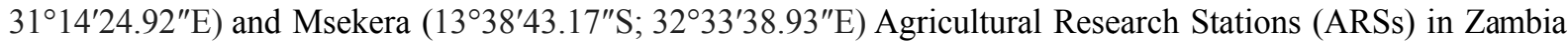
where the Organic Resource Management to Build Soil Fertility Project (http://www.r4d.ch/modules/ food-security/building-soil-fertility) was implemented. The locations of Misamfu and Msekera ARS are presented in Figure 1. Misamfu ARS is at an average elevation of $1536 \mathrm{~m}$ above sea level, while Msekera ARS is $1030 \mathrm{~m}$ above sea level. The average air temperature during the growing season ranges from $23{ }^{\circ} \mathrm{C}$ to $25{ }^{\circ} \mathrm{C}$ and from $16{ }^{\circ} \mathrm{C}$ to $24{ }^{\circ} \mathrm{C}$ at Msekera ARS and Misamfu ARS respectively. The soil at Msekera was a Paleustult (Veldkamp, 1987) with a sandy clay loam surface horizon while the soil Misamfu was a Kandiustult (Magai, 1985 ) with a loamy sand surface horizon. These two soils are representative of extensively cultivated agricultural soils in the Eastern and Northern Regions of Zambia. Zambia has a tropical continental climate with three distinct seasons namely (i) a cool dry season from April to August (ii) a hot dry season from September to November and (iii) a warm wet season from November to March (Muchinda \& Spaargaren, 1985). Msekera and Misamfu ARSs are in agro-ecological regions II and III of Zambia respectively. Region II has a mean annual rainfall of between 800 to $1000 \mathrm{~mm}$ while region III receives more than $1000 \mathrm{~mm}$ rainfall.

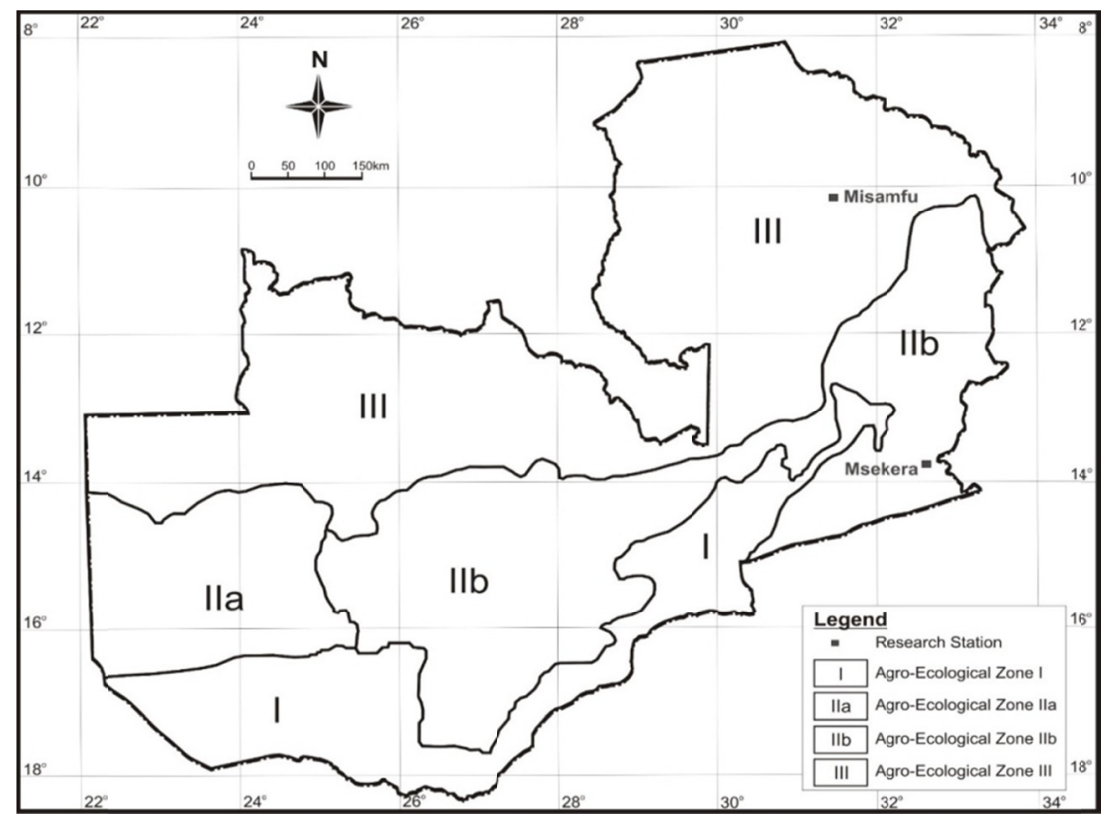

Figure 1. Map of Zambia showing the agro-ecological regions and locations of Misamfu and Msekera ARS 
The field experiment at both sites was laid out in a randomized complete block design (RCBD) in $10 \times 10 \mathrm{~m}$ plots with four replicates at Misamfu ARS and five replicates at Msekera ARS. There were eight treatments at Misamfu ARS and nine treatments at Msekera ARS.

\subsection{Description of Treatments Used in the Study}

The organic inputs used in the incubation study were part of the treatments used in field experiments by the ORM4Soil Project at Misamfu and Msekera ARSs. Inputs used in the field experiments at each location had been selected following recommendations from local farmers through a participatory rural appraisal to identify traditional and researcher-recommended soil fertility management practices with the potential of improving soil fertility on small-scale farmers' fields. The treatments recommended by researchers at both ARSs were interplants of maize with Cajanus cajan (pigeon peas) and with Tephrosia vogelii (tephrosia). Besides these two interplants, a further interplant of maize with Crotalaria juncea (black sunnhemp) was included at Msekera ARS All the interplant systems included the use of chemical fertilizers consisting of Compound D fertilizer $(10 \% \mathrm{~N}$ : $\left.20 \% \mathrm{P}_{2} \mathrm{O}_{5}: 10 \% \mathrm{~K}_{2} \mathrm{O}\right)$ used as a basal dressing fertilizer and urea $(46 \% \mathrm{~N})$ used as a top-dressing fertilizer. The chemical fertilizers were applied at full $(200 \mathrm{~kg} / \mathrm{ha})$ and half $(100 \mathrm{~kg} / \mathrm{ha})$ of the recommended rate for small-scale farmers in Zambia.

The traditional soil fertility management practices used was the Fundikila system at Misamfu ARS and composted cattle manure at Msekera ARS. The Fundikila system involves burying native grasses and shrubs under large soil ridges towards the end of the growing season at the end of March to early April. The organic inputs decompose under the ridges, until the ridges are opened-up and flattened before the onset of the rainy season in early December and the crop is then planted. A modification of the traditional Fundikila system which consisted of burying biomass of velvet beans (Mucuna pruriens) grown from December to April instead of the native grasses and shrubs was included at Misamfu ARS. The traditional Fundikila was tested in combination with the full rates of Compound D and urea fertilizers as practiced by farmers, while the modified Fundikila was assessed with full and half rates of the chemical fertilizers. The composted cattle manure was used singly or in combination with half of the recommended rate of Compound D fertilizer. A conventional treatment consisting of a maize monocrop with full rates of Compound D and urea was included in both sites as a control treatment. For the laboratory study all treatments except the control received an equivalent of $4,877 \mathrm{~kg}$ maize stover biomass /ha. Table 1 gives a summary of the treatments used on the two soils and the associated treatment codes.

Table 1. Codes and description of field treatments used in the study

\begin{tabular}{|c|c|c|c|}
\hline Treatment Code & Amount (kg/ha) and type of organic inputs applied & Amount (kg/ha) and type of fertilizer applied & Soil Used \\
\hline PpSF & 6121 pigeon pea $+4,877$ maize stover & $200 \mathrm{D}+200$ Urea & LS and SCL \\
\hline $\mathrm{PpSF}_{1 / 2}$ & 6121 pigeon pea $+4,877$ maize stover & $100 \mathrm{D}+100$ Urea & LS and SCL \\
\hline TepSF & 8014 tephrosia $+4,877$ maize stover & $200 \mathrm{D}+200$ Urea & LS and SCL \\
\hline TepSF $_{1 / 2}$ & 8014 tephrosia $+4,877$ maize stover & $100 \mathrm{D}+100$ Urea & LS and SCL \\
\hline SunnSF & 7,812 sunnhemp $+4,877$ maize stover & $200 \mathrm{D}+200$ Urea & SCL \\
\hline SunnSF $_{1 / 2}$ & 7,812 sunnhemp $+4,877$ maize stover & $100 \mathrm{D}+100$ Urea & SCL \\
\hline $\mathrm{VvSF}_{1 / 2}$ & 10,328 velvet bean $+4,877$ maize stover & $100 \mathrm{D}+100$ Urea & LS \\
\hline VvS & 10,328 velvet bean $+4,877$ maize stover & $0 \mathrm{D}+0$ Urea & LS \\
\hline IndSF & 20,480 native grasses and shrubs $+4,877$ maize stover & $200 \mathrm{D}+200$ Urea & LS \\
\hline $\operatorname{ManSF}_{1 / 2}$ & 20,000 composted cattle manure $+4,877$ maize stover & $100 \mathrm{D}+0$ Urea & SCL \\
\hline ManS & 20,000 composted cattle manure $+4,877$ maize stover & $0 \mathrm{D}+0$ Urea & SCL \\
\hline SF & 4,877 maize stover & $200 \mathrm{D}+200$ Urea & LS and SCL \\
\hline Cont & -None- & $0 \mathrm{D}+0$ Urea & LS and SCL \\
\hline
\end{tabular}

\subsection{Characterization of Soils and Organic Inputs Used in the Study}

Air dried soil samples that had passed through a $2 \mathrm{~mm}$ mesh size were tested for their $\mathrm{pH}$ in $0.01 \mathrm{M} \mathrm{CaCl}_{2}$ at a soil to solution ratio of 1:2.5 (McLean, 1973). Soil organic carbon was determined by the potassium dichromate wet oxidation method (Nelson \& Sommers, 1982); total nitrogen $(\mathrm{N})$ by the Kjeldahl distillation method (Jones, 2001) following digestion with concentrated $\mathrm{H}_{2} \mathrm{SO}_{4}$; available phosphorus (P) by the Bray 1 method (Jones, 2001); and exchangeable potassium (K) using the $1 \mathrm{M}$ ammonium acetate method (Chapman, 1965). The particle size distribution was determined using the hydrometer method (Jones, 2001) while the bulk density was determined using the core ring method (Casanova, Tapia, Seguel \& Salazar, 2016). 
The plant biomasses and composted cow manure were air-dried under a shed for a week and then oven-dried at $65^{\circ} \mathrm{C}$ for 48 hours (Campbell \& Plank, 1998; Dalal, Sahrawat, \& Meyers, 1984). The organic materials were then milled using a Thomas-Wiley Laboratory mill (Model 4) and sieved using a $2 \mathrm{~mm}$ mesh size sieve. Total nitrogen contents of organic materials were determined using the salicyclic-thiosulphate method described by Amin and Flowers (2004). The total $\mathrm{K}$ and $\mathrm{P}$ were extracted by dry-ashing and digested in $1 \mathrm{M}$ nitric acid (Jones, 2001). Concentrations of $K$ in the extracts were determined on a Perkin Elmer Analyst 400 Atomic Absorption Spectrophotometer while concentrations of $\mathrm{P}$ were determined using a JENWAY $6305 \mathrm{UV} /$ Visible spectrophotometer at a wavelength of $882 \mathrm{~nm}$. The organic carbon content of the plant materials was determined by the Walkley and Black method (Okalebo, Gathua, \& Woomer, 2002; Schumacher, 2002). The characteristics of the organic inputs are as shown in Table 3.

\subsection{Set-Up of Incubation Study}

The incubation experiment was conducted over 13 weeks to reflect the average growth period of early maturing maize varieties, which according to Oluwaranti, Fakorede and Badu-Apraku (2008) ranges from 80 to 95 days. The 13-week period also corresponds to observed recent duration of the rainy season, when microbial activity is not limited by the availability of water in the field in the agro-ecological region II of Zambia which is the major maize-growing region, in Zambia.

A $100 \mathrm{~g}$ of air-dried soil mixed with organic inputs with or without chemical fertilizer was moistened to $60 \%$ of total porosity of the soil (Samuel \& Ebenezer 2014) and placed in a 1 L plastic jar with a screwable lid. The control treatment consisted of soil alone. A $100 \mathrm{~cm}^{3}$ beaker containing $5 \mathrm{~mL}$ of $0.2 \mathrm{M} \mathrm{KOH}$ was placed inside the $1 \mathrm{~L} \mathrm{jar}$, which was closed air tightly and kept at room temperature. The average room temperature was $22{ }^{\circ} \mathrm{C}$ during the incubation period. The amount of mineralized carbon was determined by titrating the alkali solution that absorbed $\mathrm{CO}_{2}$ with $0.1 \mathrm{M} \mathrm{HCl}$ (Kirita, 1971). After every measurement of $\mathrm{CO}_{2}$ emissions, the soils were moistened to maintain a moisture content corresponding to $60 \%$ of the total porosity of the soil. This was done by weighing each jar and adding the required amount of water with a pipette. The experiment was laid out in a Completely Randomized Design (CRD) with four replicates. Carbon dioxide emissions were measured and recorded weekly during the first nine weeks, and fortnightly thereafter.

\subsection{Determination of Mineralized Carbon}

The emission of carbon as a percentage of the total carbon present in the soil was determined using Equation 1 below:

$$
\% \mathrm{CO}_{2}-\mathrm{C} \text { loss }=\left[C_{\text {emit }} /\left(C_{\text {appl }}+C_{\text {soil }}\right)\right] \times 100
$$

Where,

$C_{\text {emit }}$ is the total amount of carbon emitted during the 13 weeks in $\mathrm{mg} \mathrm{kg} \mathrm{soil}{ }^{-1} ; C_{a p p l}$ is the amount of carbon applied as input in $\mathrm{mg} \mathrm{kg} \mathrm{soil}{ }^{-1} ; C_{\text {soil }}$ is the initial soil organic carbon in $\mathrm{mg} \mathrm{kg}$ soil $^{-1}$.

The $\% \mathrm{CO}_{2}-\mathrm{C}$ emission based on $\mathrm{C}$ applied to the soil is given by Equation 2.

$$
\% \text { C emission }=\left[\left(C_{\text {treat }}-C_{\text {cont }}\right) / C_{\text {appl }}\right] \times 100
$$

Where,

$C_{\text {treat }}$ is the cumulative $\mathrm{C}$ emitted from the treatment in $\mathrm{mg} \mathrm{kg} \mathrm{soil}^{-1} ; C_{\text {cont }}$ is the cumulative $\mathrm{C}$ emitted from the control treatment in $\mathrm{mg} \mathrm{kg} \mathrm{soil}{ }^{-1} ; C_{\text {appl }}$ is the amount of carbon applied as input in $\mathrm{mg} \mathrm{kg} \mathrm{soil}{ }^{-1}$.

The carbon mineralization rate constant was determined from the first-order kinetics equation as described in Equation 3 (Stanford \& Smith, 1972; Moretti, Bertoncini, \& Abreu-Junior, 2017).

$$
\mathrm{CO}_{2}-C_{\text {cum }}=C_{t o}\left(1-e^{-k t}\right)
$$

Where,

$\mathrm{CO}_{2}-C_{\text {cum }}$ is the amount of carbon mineralized during the incubation experiment; $C_{t o}$ is the potential mineralizable carbon in the sample; $k$ is the carbon mineralization rate constant.

The mean residence time (MRT) of organic carbon, which is defined as the average time that a particular element resides in a given pool at a steady-state (Six \& Jastrow 2002) was determined using Equation 4.

$$
M R T=1 / k
$$

Where, $k$ is the mineralization rate constant. 


\subsection{Statistical Analyses}

To determine whether there were significant differences among treatment means an Analysis of Variance (ANOVA) was carried out, and Duncan's Multiple Range Test was used to separate the treatment means when results of the ANOVA indicated the presence of significant differences among treatment means. The analyses were conducted using the SAS software version 9.0 for windows.

\section{Results}

\subsection{Properties of the Soil and Organic Inputs}

The properties of the two soils used for the study are presented in Table 2 . The soils were very strongly acid and had moderate levels of organic matter. The levels of total $\mathrm{N}$ were low on the loamy sand (LS) soil from Misamfu and very low on the sandy clay loam (SCL) soil from Msekera. The soils had higher levels of K than the critical value of $0.2 \mathrm{cmol} \mathrm{kg}^{-1}$, while the available P was very low on the SCL and very high on the LS according to the interpretation by Hazelton and Murphy (2007).

Table 2. Mean values with standard errors of selected properties of soils used in the study

\begin{tabular}{lll}
\hline \multirow{2}{*}{ Soil Property } & \multicolumn{2}{c}{ Study Site } \\
\cline { 2 - 3 } & Msekera & Misamfu \\
\hline USDA Textural class & Sandy clay loam & Loamy Sand \\
pH $\left(0.01 \mathrm{M} \mathrm{CaCl}_{2}\right)$ & $4.39 \pm 0.04$ & $4.33 \pm 0.04$ \\
Organic matter $(\%)$ & $2.42 \pm 0.12$ & $2.53 \pm 0.15$ \\
Bray1-phosphorus $\left(\mathrm{mg} \mathrm{kg}^{-1}\right.$ soil) & $5.38 \pm 0.43$ & $25.15 \pm 0.17$ \\
Exchangeable potassium (cmol.kg soil $\left.{ }^{-1}\right)$ & $0.69 \pm 0.02$ & $0.44 \pm 0.06$ \\
Total nitrogen (\%) & $0.03 \pm 0.01$ & $0.09 \pm 0.01$ \\
Bulk Density $\left(\mathrm{Mg} \mathrm{m}^{-3}\right)$ & $1.48 \pm 0.03$ & $1.38 \pm 0.00$ \\
Sand (\%) & $58.8 \pm 1.31$ & $82.8 \pm 0.40$ \\
Silt (\%) & $14.0 \pm 1.34$ & $6.4 \pm 0.40$ \\
Clay (\%) & $27.2 \pm 1.04$ & $10.8 \pm 0.00$ \\
\hline
\end{tabular}

Selected properties of the organic inputs are shown in Table 3. Maize stover and pigeon pea biomass had the highest $\mathrm{C}$ content of about $57 \%$, followed by Tephrosia, sunnhemp and velvet beans with about $54 \% \mathrm{C}$, while the traditional inputs - cattle manure and indigenous biomass, had the lowest $\mathrm{C}$ contents of less than $50 \%$. The velvet bean biomass had the highest contents of total N, P and $\mathrm{K}$ while the maize stover had the lowest $\mathrm{N}, \mathrm{P}$ and $\mathrm{K}$. The legume biomasses had higher $\mathrm{N}$ content than the indigenous biomass and maize stover. The $\mathrm{C}: \mathrm{N}$ ratios of the organic inputs were in the order: velvet beans $<$ sunnhemp $<$ tephrosia $<$ composted manure $<$ pigeon peas $<$ indigenous biomass $<$ maize stover.

Table 3. Mean values with standard errors of selected properties of organic inputs used

\begin{tabular}{llllll}
\hline Organic input & $\% \mathrm{~N}$ & $\% \mathrm{~K}$ & $\% \mathrm{P}$ & $\% \mathrm{C}$ & $\mathrm{C} / \mathrm{N}$ ratio \\
\hline Composted cattle manure & $1.87 \pm 0.04$ & $2.00 \pm 0.05$ & $0.36 \pm 0.02$ & $35.16 \pm 0.23$ & 18.80 \\
Indigenous biomass & $1.11 \pm 0.06$ & $2.03 \pm 0.02$ & $0.16 \pm 0.01$ & $49.20 \pm 0.68$ & 44.30 \\
Pigeon peas & $2.23 \pm 0.03$ & $1.72 \pm 0.07$ & $0.22 \pm 0.01$ & $56.48 \pm 0.15$ & 25.30 \\
Tephrosia & $2.84 \pm 0.07$ & $0.99 \pm 0.04$ & $0.21 \pm 0.02$ & $54.48 \pm 0.20$ & 18.10 \\
Sunnhemp & $3.18 \pm 0.12$ & $1.47 \pm 0.06$ & $0.33 \pm 0.02$ & $54.48 \pm 0.27$ & 17.10 \\
velvet beans & $3.56 \pm 0.19$ & $2.30 \pm 0.06$ & $0.38 \pm 0.01$ & $53.36 \pm 0.37$ & 15.00 \\
Maize stover & $0.48 \pm 0.05$ & $1.42 \pm 0.04$ & $0.19 \pm 0.01$ & $56.56 \pm 0.55$ & 118.00 \\
\hline
\end{tabular}

\section{2 $\mathrm{CO}_{2}$-C Emissions}

The $\mathrm{CO}_{2}-\mathrm{C}$ losses from different treatments on the two soils are shown in Table 4. The total $\mathrm{CO}_{2}-\mathrm{C}$ evolved from the control treatments was significantly lower $(p<0.05)$ than those from treatments with organic inputs with or without chemical fertilizer in both soils. No statistically significant differences $(\mathrm{p}<0.05)$ in the total $\mathrm{CO}_{2}-\mathrm{C}$ emissions were observed among the other treatments on the SCL. On the LS, the pigeon pea with full rate of chemical fertilizer (PpSF) had significantly higher total $\mathrm{CO}_{2}-\mathrm{C}$ emissions than the control and the conventional treatments (SF). There were no statistically significant differences in the total $\mathrm{CO}_{2}-\mathrm{C}$ emissions among the other 
treatments on the LS. The effects of the treatments on $\mathrm{CO}_{2}$ emissions were evident on the LS where significant differences $(\mathrm{p}<0.05)$ in total $\mathrm{CO}_{2}-\mathrm{C}$ emissions and percentage $\mathrm{C}$ lost from the inputs were observed.

Table 4. Total $\mathrm{CO}_{2}-\mathrm{C}$ emissions, and fractional seasonal $\mathrm{C}$ losses of the total organic $\mathrm{C}$ and applied organic $\mathrm{C}$ for different treatments in the two soils

\begin{tabular}{|c|c|c|c|c|c|c|c|}
\hline \multicolumn{4}{|c|}{ Loamy Sand } & \multicolumn{4}{|c|}{ Sandy Clay Loam } \\
\hline Treat.* & $\begin{array}{l}\text { Total } \mathrm{CO}_{2}-\mathrm{C} \\
\text { lost }(\mathrm{mg} / \mathrm{kg})\end{array}$ & $\begin{array}{l}\text { Percentage of } \\
\text { total C lost (\%) }\end{array}$ & $\begin{array}{l}\text { Percentage of } \\
\text { applied C lost (\%) }\end{array}$ & Treat.* & $\begin{array}{l}\text { Total } \mathrm{CO}_{2}-\mathrm{C} \\
\text { lost }(\mathrm{mg} / \mathrm{kg})\end{array}$ & $\begin{array}{l}\text { Percentage of } \\
\text { total C lost (\%) }\end{array}$ & $\begin{array}{l}\text { Percentage of } \\
\text { applied C lost (\%) }\end{array}$ \\
\hline PpSF & $486.6 \mathrm{a}$ & $3.27 \mathrm{a}$ & $12.18 \mathrm{~b}$ & PpSF & $432.0 \mathrm{a}$ & $3.04 \mathrm{a}$ & $10.48 \mathrm{bc}$ \\
\hline $\mathrm{PpSF}^{1 / 2}$ & $462.8 \mathrm{ba}$ & $2.96 \mathrm{ba}$ & $11.15 \mathrm{~b}$ & $\mathrm{PpSF}^{1} / 2$ & $452.7 \mathrm{a}$ & $3.19 \mathrm{a}$ & $11.45 \mathrm{~b}$ \\
\hline TepSF & 447.6ba & $2.96 \mathrm{ba}$ & $9.45 \mathrm{bc}$ & TepSF & $447.3 \mathrm{a}$ & $3.10 \mathrm{a}$ & $10.13 \mathrm{bcd}$ \\
\hline $\operatorname{TepSF}^{1 / 2}$ & $410.1 \mathrm{ba}$ & $2.71 \mathrm{~b}$ & $7.95 \mathrm{bc}$ & $\mathrm{TepSF}^{1 / 2}$ & $453.6 \mathrm{a}$ & $3.15 \mathrm{a}$ & $10.38 \mathrm{bc}$ \\
\hline $\mathrm{VvSF}^{1 / 2}$ & $462.9 \mathrm{ba}$ & $3.11 \mathrm{ba}$ & $8.35 \mathrm{cb}$ & SunnSF & $460.2 \mathrm{a}$ & $3.18 \mathrm{a}$ & $10.48 \mathrm{bc}$ \\
\hline $\mathrm{VvS}$ & 456.6ba & $2.92 \mathrm{ba}$ & $8.15 b c$ & SunnSF $1 / 2$ & $468.3 \mathrm{a}$ & $3.24 \mathrm{a}$ & $10.83 \mathrm{bc}$ \\
\hline IndSF & $449.7 \mathrm{ba}$ & $2.64 \mathrm{~b}$ & $5.38 \mathrm{c}$ & ManSF $1 / 2$ & $479.1 \mathrm{a}$ & $3.11 \mathrm{a}$ & $8.08 \mathrm{~cd}$ \\
\hline $\mathrm{SF}$ & $384.3 b$ & $2.82 \mathrm{ba}$ & $17.23 \mathrm{a}$ & ManS & $450.6 \mathrm{a}$ & $2.92 \mathrm{a}$ & $7.23 \mathrm{~d}$ \\
\hline \multirow[t]{2}{*}{ Cont } & $212.1 \mathrm{c}$ & $1.68 \mathrm{c}$ & NA & $\mathrm{SF}$ & $422.1 \mathrm{a}$ & $3.24 \mathrm{a}$ & $22.53 \mathrm{a}$ \\
\hline & & & & Cont & $358.2 \mathrm{~b}$ & $2.96 \mathrm{a}$ & NA \\
\hline
\end{tabular}

Note. *Treatment means within a column followed by the same subscripts are not significantly different at 0.05 level of significance using Duncan's Multiple Range Test. *All treatment codes are as described in Table 1.

\subsection{Mineralization Rate Constants ( $k$ ) and Mean Residence Times (MRT) of the Organic Carbon}

The $\mathrm{k}$ and MRTs of organic carbon for the different treatments on the two soils are shown in Table 5. The MRT of soil organic carbon ranged from about 5 to 59 seasons on the LS and from 13 to 32 seasons on the SCL. The control treatments had the lowest $\mathrm{k}$ on both soils and consequently had the highest MRTs. In contrast, the conventional treatments on both soils had the highest $\mathrm{k}$ and the lowest corresponding MRTs.

Table 5. Carbon mineralization constants (k) and Mean Residence times (MRT) of organic carbon in different treatments on the two soils

\begin{tabular}{|c|c|c|c|c|c|}
\hline \multicolumn{3}{|c|}{ Loamy sand soil } & \multicolumn{3}{|c|}{ Sandy clay loam soil } \\
\hline Treatment* & $\mathrm{k}\left(\mathrm{wk}^{-1}\right)$ & MRT (13wk seasons) & Treatment & $\mathrm{k}\left(\right.$ week $\left.^{-1}\right)$ & MRT (13wk seasons) \\
\hline PpSF & 0.0108 & 7.1 & $\mathrm{PpSF}$ & 0.0032 & 24.0 \\
\hline $\mathrm{PpSF}^{1 / 2}$ & 0.0101 & 7.6 & $\mathrm{PpSF}^{1 / 2}$ & 0.0040 & 19.2 \\
\hline TepSF & 0.0082 & 9.4 & TepSF & 0.0037 & 20.8 \\
\hline TepSF $1 / 2$ & 0.0068 & 11.3 & $\mathrm{TepSF}^{1 / 2}$ & 0.0037 & 20.8 \\
\hline $\mathrm{VvSF}^{1} / 2$ & 0.0073 & 10.5 & SunnSF & 0.0037 & 20.8 \\
\hline VvS & 0.0073 & 10.5 & SunnSF $1 / 2$ & 0.0045 & 17.1 \\
\hline IndSF1 & 0.0049 & 15.7 & $\mathrm{ManSF}^{1 / 2}$ & 0.0034 & 22.6 \\
\hline $\mathrm{SF}$ & 0.0170 & 4.5 & ManS & 0.0029 & 26.5 \\
\hline \multirow[t]{2}{*}{ Cont } & 0.0013 & 59.2 & $\mathrm{SF}$ & 0.0058 & 13.3 \\
\hline & & & Cont & 0.0024 & 32.1 \\
\hline
\end{tabular}

Note. *All treatment codes are as described in Table 1.

The $\mathrm{k}$ and MRTs of organic carbon for groups of treatments are shown in Table 6. In both soils, the stability of soil organic carbon in the different treatments was in the order of Control $>$ Traditional $>$ Legumes $>$ Conventional. Treatments with lower $\mathrm{k}$ emitted less carbon and had correspondingly longer MRTs. 
Table 6. Means of C mineralization rate constants (k) and Mean Residence Times (MRT) of grouped treatments in the two soils

\begin{tabular}{llllll}
\hline Grouped & \multicolumn{3}{c}{ Loamy Sand } & & \multicolumn{2}{c}{ Sandy Clay Loam } \\
\cline { 2 - 3 } \cline { 5 - 6 } Treatments & $\mathrm{k}\left(\mathrm{wk}^{-1}\right)$ & MRT $(13 \mathrm{wk}$ seasons $)$ & & $\mathrm{k}\left(\mathrm{wk}^{-1}\right)$ & MRT $(13 \mathrm{wk}$ seasons $)$ \\
\hline Control & $0.0013 \mathrm{c}$ & $59.0 \mathrm{a}$ & & $0.0024 \mathrm{c}$ & $32.0 \mathrm{a}$ \\
Traditional & $0.0049 \mathrm{~b}$ & $16.0 \mathrm{~b}$ & & $0.0032 \mathrm{bc}$ & $25.0 \mathrm{~b}$ \\
Legumes & $0.0084 \mathrm{~b}$ & $9.5 \mathrm{c}$ & & $0.0038 \mathrm{~b}$ & $20.5 \mathrm{~b}$ \\
Conventional & $0.0170 \mathrm{a}$ & $5.0 \mathrm{c}$ & & $0.0058 \mathrm{a}$ & $13.0 \mathrm{c}$ \\
Average & 0.0079 & 9.74 & & 0.0038 & 20.24 \\
\hline
\end{tabular}

Note. Treatment means within a column followed by the same subscripts are not significantly different at 0.05 level of significance using Duncan's Multiple Range Test.

* Traditional on LS = IndSF; traditional on $\mathrm{SCL}=\mathrm{ManS}$ and ManSF $1 / 2$; legumes on $\mathrm{LS}=\mathrm{VvS}, \mathrm{VvSF}^{1} / 2, \mathrm{TepSF}^{1 / 2}$,

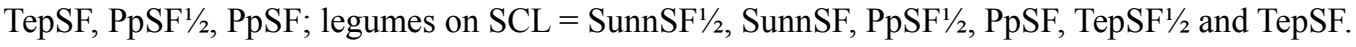

Table 7 shows the $\mathrm{k}$ and MRTs of $\mathrm{C}$ on aggregated treatments on the two soils with and without application of chemical fertilizer. Applying chemical fertilizers to the soil significantly $(\mathrm{p}<0.05)$ increased the rate of $\mathrm{C}$ mineralization and significantly $(\mathrm{p}<0.05)$ reduced the MRT of the organic carbon on both soils.

Table 7. Means of $\mathrm{C}$ mineralization rate constants $(\mathrm{k})$ and Mean Residence Times of aggregated treatments with and without chemical fertilizer on the two soils

\begin{tabular}{|c|c|c|c|c|c|c|}
\hline \multirow{2}{*}{ Treatments * } & \multicolumn{3}{|c|}{ Loamy Sand } & \multicolumn{3}{|c|}{ Sandy Clay Loam } \\
\hline & $\mathrm{n}$ & $\mathrm{k}$ & MRT & $\mathrm{n}$ & $\mathrm{k}$ & MRT \\
\hline Without chemical fertilizer & 2 & $0.0043 b$ & $35.0 \mathrm{a}$ & 2 & $0.0027 b$ & $29.5 \mathrm{a}$ \\
\hline With chemical fertilizer & 7 & $0.0093 a$ & $9.6 \mathrm{~b}$ & 8 & $0.0040 \mathrm{a}$ & $19.9 \mathrm{~b}$ \\
\hline
\end{tabular}

Note. Treatment means within a column followed by the same subscripts are not significantly different at 0.05 level of significance using Duncan's Multiple Range Test.

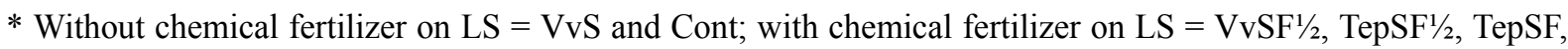
$\mathrm{PpSF}^{1 / 2}$, PpSF, IndSF, SF; without fertilizer on SCL = Cont and ManS; with chemical fertilizer on SCL = PpSF, $\mathrm{PpSF}^{1 / 2}$, TepSF, TepSF 12 , SunnSF, SunnSF $1 / 2, \mathrm{ManSF}^{1} / 2, \mathrm{SF}$; without chemical fertilizer on $\mathrm{SCL}=$ Cont and ManS.

\section{Discussion}

\subsection{Effects of Organic Inputs on Carbon Mineralization}

The addition of organic inputs with and without chemical fertilizer significantly $(\mathrm{p}<0.05)$ increased $\mathrm{CO}_{2}-\mathrm{C}$ emissions compared to the control on both soils. The increases in $\mathrm{C}$ emissions compared to the control ranged from 81 to $129 \%$ on the loamy sand, and 18 to $34 \%$ on the sandy clay loam. This was as expected as the addition of fresh organic matter normally stimulates microbial activity resulting in increased $\mathrm{C}$ mineralization. These results corroborate the assertion of Hossain et al. (2017) that the nature and quantity of organic inputs applied to soils have an influence on the rate of soil carbon emissions. There were significant differences in the proportion of applied $\mathrm{C}$ lost from different treatments on both soils. The conventional farming (SF) treatment with maize stover biomass as the main organic input and a full rate of chemical fertilizer had the highest C losses of $17.2 \%$ on the LS and $22.5 \%$ on the SCL.

Composted cow manure, the traditional organic input used by farmers in the Eastern Province of Zambia had the lowest rate of $\mathrm{C}$ lost from organic inputs on the sandy clay loam soil. This could be attributed to the composting process which removed significant amounts of labile carbon from the manure leaving it with more stable carbon compared to the other organic inputs used the study. According to Coleman (1989), besides the C: N ratio, carbon mineralization from organic inputs is also influenced by their lignin and polyphenolic contents. On the loamy sand soil, the treatment with indigenous biomass (IndSF) traditionally used by farmers in the Northern Province of Zambia had the lowest rate of C loss per C applied of 5.4\%. These results indicate that on both soils from the two agro-ecological regions, treatments representing traditional farming practices had lower losses of $\mathrm{C}$ from the soil, compared to treatments with legumes suggested by researchers as means of shortening fallow periods, and to the conventional farming practices that rely on the use chemical fertilizers. 
As discussed above, among the treatments that received organic inputs, the treatments representing traditional farming practices on both soils had the longest MRTs of 16 seasons on the LS and 25 seasons on the SCL, while the shortest MRTs on both soils were those of treatments representing the conventional farming practices (SF) with mean values of 5 seasons on the LS and 13 seasons on the SCL. The longer MRT of organic C in traditional farming practices compared to conventional farming practices and to treatments with leguminous plant biomass is worth noting when considering sustainable management of soil organic matter and carbon sequestration in the soils. The observed shorter MRT of organic $\mathrm{C}$ in soils under the conventional farming treatments in this study corroborates the argument of Chirinda et al. (2009) that conventional cropping systems, that rely on chemical fertilizers and focus on short-term management of soil fertility may not be appropriate for improving soil organic matter and sequestering carbon. As indicated by Palm Gachengo, Delve, Cadisch and Giller (2000), a balance between the long-term maintenance of soil organic matter and soil carbon sequestration with the short-term crop nutrient is required for sustainable soil fertility management. The use of leguminous organic inputs with intermediate MRTs could help achieve the goal of balancing short-term soil fertility requirements with the long-term goal of maintaining soil organic matter.

\subsection{Effect of Applying Chemical Fertilizer on Carbon Mineralization}

The aggregated effect of chemical fertilizer application across treatments on $\mathrm{C}$ mineralization on the two soils shows that applying chemical fertilizer significantly increased carbon mineralization rates. The increases in $\mathrm{CO}_{2}$ emissions due to fertilizer application were about $116 \%$ on the LS, and $48 \%$ on the SCL. There were corresponding significant $(\mathrm{p}<0.05)$ reductions in the MRT of the organic carbon by $73 \%$ on the loamy sand soil, and by $33 \%$ on the sandy clay loam soil as a result of application of chemical fertilizer. The reductions in the MRT on sandy loam were from 35 seasons without fertilizer to about 10 seasons with chemical fertilizer and from 30 seasons without chemical to about 20 years with chemical fertilizer on the sandy clay loam.

No significant differences in $\mathrm{C}$ emissions were observed between the two rates of chemical fertilizers used in the study on the SCL loam. However, some general trends were observed on the two soils regarding treatments with the same type of organic inputs. On the loamy sand higher $\mathrm{CO}_{2}-\mathrm{C}$ emissions were associated with higher rates of chemical fertilizer, while on the SCL soil, higher $\mathrm{CO}_{2}-\mathrm{C}$ emissions generally occurred on treatments with lower rates of chemical fertilizer. The trend observed on the SCL is similar to the findings of Nyamangara, Mtambanengwe and Musvoto (2009) in Zimbabwe, where a reduction in C mineralization rates was observed upon addition of nitrogenous chemical fertilizer. According to Manzoni, Jackson, Trofymow and Porporato (2008) this could be due to the enhanced carbon-utilization efficiency of soil microbes associated with $\mathrm{N}$ fertilizer application which results in reduced $\mathrm{CO}_{2}$ emissions.

\subsection{Effect of Soil Texture on Carbon Mineralization}

Although there were only two soil textural classes evaluated in this study, results in Table 6 show that the carbon mineralization rate was generally higher on the on the LS than on the SCL. The overall mean carbon mineralization rate constant $\mathrm{k}$ on the sandy loam of $0.0079 \mathrm{wk}^{-1}$ was about twice that on the sandy clay loam of $0.0038 \mathrm{wk}^{-1}$, with corresponding MRTs of about 10 seasons for the loamy sand and about 20 seasons for the sandy clay loam. Longer MRTs of carbon on the SCL compared to the LS could be attributed to the higher clay content of the SCL of about $27 \%$ compared to $10 \%$ of the LS. Clay is reported to have a protective effect on soil organic matter which enhances the storage of carbon in soils, a phenomenon Rakhsh, Golchin, Agha and Alandari (2017) refer to as the "carbon storage effect of clay".

\section{Conclusion}

Based on the results and foregoing discussion it was concluded that the factors that significantly influenced carbon mineralization in the surface samples of the two Ultisols were the type of organic inputs, the addition of chemical fertilizer and the texture of the soil.

\section{Acknowledgements}

The authors gratefully acknowledge the financial support received from the Swiss Programmed for Research on Global Issues for Development and the Swiss National Science Foundation through the Research Institute of Organic Agriculture (FiBL) for this study. The authors acknowledge the useful comments and support from Dr. Andreas Fliessbach, Dr. Alice M. Mweetwa, and the help from laboratory staff of the Department of Soil Science at the University of Zambia. 


\section{References}

Ajayi, O. C., Akinnifesi, F. K., Sileshi, G., \& Chakeredza, S. (2007). Adoption of Renewable Soil Fertility Replenishment Technologies in the Southern African Region: Lessons Learnt and the Way Forward. Nat Resour Forum, 31, 306-317.

Ambrosano, E. J., Trivelin, P. C. O., Cantarella, H., Ambrosano, G. M. B., \& Muraoka, T. (2003). Nitrogen Mineralization in Soils Amended with Sunnhemp, Velvet Bean and Common Bean Residues. Sci Agric, 60(1), 133-137.

Amin, M., \& Flowers, T. H. (2004). Evaluation of the Kjeldhal Method. J Res Sci, 15(2), 159-179.

Bationo, A., Hartemink, A., Lungu, O., Naimi, M., Okoth, P., Smaling, E., ... Waswa, B. (2012). Knowing the African soils to improve fertilizer recommendations. In J. Kihara, D. Fatondji, J. W. Jones, G. Hoogenboom, R. Tabo, \& A. Bationo (Eds.), Improving soil fertility recommendations in Africa using the decision support system for agrotechnology transfer (DSSAT). https://doi.org/10.1007/978-94-007-2960-5_3

Bhatia, A., Pathak, H., Jain, N., Singh, P. K., \& Singh, A. K. (2005). Global Warming Potential of Manure Amended Soils under Rice-wheat System in the Indo-gangetic Plains. J. Atmosenv., 39, 6976-6984. https://doi.org/10.1016/j.atmosenv.2005.07.052

Bindraban, P. S., Batjes, N. H., Leenars, J. G. B., \& Bai, Z. (2010). Relevance of Soil and terrain information in studies of major global issues. $19^{\text {th }}$ World Congress of Soil Science, Brisbane.

Bouajila, K., \& Sanaa, M. (2011). Effects of Organic Amendments on Soil Physico-chemical and Biological Properties. J Mater Environ Sci, 2(1), 485-490.

Campbel, C. R., \& Plank, C. D. (1998). Preparation of plant tissue for laboratory analysis. In Y. P. Kalra (Ed.), Handbook of reference methods for plant analysis. London: CRC Press.

Casanova, M., Tapia, E., Seguel, O., \& Salazar, O. (2016). Direct Measurement and Prediction of Bulk Density on Alluvial Soils of Central Chile. Chilean Journal of Agricultural Research, 76(1), 105-113. https://doi.org/10.4067/S0718-58392016000100015

Castellanos-Navarrete, A., Tittonell, P., Rufino, M. C., \& Giller, K. E. (2015). Feeding, Crop Residue and Manure Management for Integrated Soil Fertility Management-A Case Study from Kenya. Agricultural Systems, 134, 24-35. https://doi.org/10.1016/j.agsy.2014.03.001

Chapman, H. D. (1965). Cation-exchange Capacity. In C. A. Black (Ed.), Methods of Soil Analysis: Chemical and Microbiological Properties (Vol. 9, pp. 891-901). Agronomy, Madison.

Chirinda, N., Carter, M. S., Albert, K. R., Ambus, P., Olesen, J. E., Porter, J. R., \& Petersen, S. O. (2010). Emissions of Nitrous Oxide from Arable Organic and Conventional Cropping Systems on two Soil Types. Agric Ecosyst Environ, 136, 199-208. https://doi.org/10.1016/j.agee.2009.11.012

Coleman, D. C., Oades, J. M., \& Uehara, J. (1989). Dynamics of soil organic matter in tropical ecosystems. Honolulu: University of Hawaii Press. https://doi.org/10.1017/S0021859600075304

Dalal, R. C., Sahrawat, K. L., \& Meyers, R. J. K. (1984). Inclusion of Nitrate and Nitrite in the Kjeldhal Nitrogen Determination of Soils and Plant Materials using Sodium Thiosulphate. Commun Soil Sci Plant Anal, 15(2), 1453-1461. https://doi.org/10.1080/00103628409367572

Delgado-Baquerizo, M., García-Palacios, P., Milla, R., Gallardo, A., \& Maestre, F. T. (2015). Soil Characteristics Determine Soil Carbon and Nitrogen Availability during Leaf Litter Decomposition Regardless of Litter Quality. Soil Biol Biochem, 81, 134-142. https://doi.org/10.1016/j.soilbio.2014.11.009

Diacono, M., \& Montemurro, F. (2010). Long-term Effect of Organic Amendments on Soil Fertility-A Review. Agron Sustain Dev., 30, 401-422. https://doi.org/10.1051/agro/2009040

Hazelton, P., \& Murphy, B. (2007). Interpreting soil test results-What do all the numbers mean? Collingwood. CSIRO Publishing.

Hossain, B., Rahman, M., Biswas, J. C., Miah, M. U., Akhter, S., Choudhury, A. K., ... Kalra, N. (2017). Carbon Mineralization and Carbon Dioxide Emission from Organic Matter added Soil under Different Temperature Regimes. Int J Recycl Org Waste Agricult, 6, 311-319. https://doi.org/10.1007/s40093-017-0179-1

Jones, J. B. (2001). Laboratory guide for conducting soil tests and plant analysis. Florida. CRS Press.

Khalafalla, M. Y., \& Hamed, M. H. (2015). Impact of Nitrogen Fertilization on Soil Organic Carbon Decomposition. Alexandria Science Exchange Journal, 36(4), 381-389. 
Kirita, H. (1971). Re-examination of the Absorption Method for Measuring Soil Respiration under Field Conditions. Measuring Soil Respiration under Field Conditions-An Improved Absorption Method using a Disc of Plastic Sponge as Absorbent Holder. Jpn. J. Ecol., 21, 119-127. https://doi.org/10.18960/ seitai.21.3-4 119

Lal, R. (1987). Managing the Soils of Sub-Saharan Africa. Science, 236(4805), 1069-1076. https://doi.org/ 10.1126/science.236.4805.1069

Lekasi, J. C., Tanner, J. C., Kimani, S. K., \& Harris, P. J. C. (2001). Manure management in the Kenya highlands: Practices and potential (2nd ed.). Kenilworth: HDRA Publications.

Magai, R. N. (1985). Field tour guide. In P. R. Woode (Ed.), Proceedings of the $11^{\text {th }}$ International Forum on Soil Taxonomy and Agrotechnological Transfer, July 15 to August 1, 1985, Zambia. IBSNAT, BADC, MAWD, NORAD, USAID, SMSS, UNZA.

Maerere, A. P., Kimbi, G. G., \& Nonga, D. L. M. (2001). Comparative Effectiveness of Animal Manures on Soil Chemical Properties, Yield and Root Growth of Amaranthus. Afr J Sc Technol, 1(4), 14-21. https://doi.org/ 10.4314/ajst.v1i4.44623

Manzoni, S., Jackson, R. B., Trofymow, J. A., \& Porporato, A. (2008). The Global Stochiometry of Litter Nitrogen Mineralization. Science, 321, 684-686. https://doi.org/10.1126/science.1159792

Matson, P. A., Parton, W. J., Power, A. G., \& Swift, M. J. (1997). Agricultural Intensification and Ecosystem Properties. Science, 277(25), 504-509. https://doi.org/10.1126/science.277.5325.504

Moretti, S. M. L., Bertoncini, E. I., \& Abreu-Junior, C. H. (2017). Carbon Mineralization in Soils Irrigated with Treated Swine Wastewater. J Agric Sci, 9(3), 9-29. https://doi.org/10.5539/jas.v9n3p19

Muchinda, M. R., \& Spaargaren, O. (1985). The Agro climate of Zambia. In P. Woode (Ed.), Proceedings of the IXth International Forum on Soil Taxonomy and Agro technological Transfer, July 15 to August 1, 1985, Zambia. IBSNAT, BADC, MAWD, NORAD, USAID, SMSS, and UNZA.

Mugwe, J., Mugendi, D., Odee, D., \& Mairura, F. (2009). Effect of Selected Organic Materials and Inorganic Fertilizer on the Soil Fertility of a Humic Nitisol in the Central Highlands of Kenya. Soil Use Manag, 25, 434-440. https://doi.org/10.1111/j.1475-2743.2009.00244.x

Mustafa-Msukwa, A. K., Mutimba, J., Masangano, C., \& Edriss, A. K. (2011). An Assessment of the Adoption of Compost Manure by Smallholder Farmers in Balaka District, Malawi. S. Afr. Jnl. Agric. Ext., 39(1), 17-25. Retrieved from http://hdl.handle.net/2263/16406

Muyayabantu, G. M., Kadiata, B. D., \& Nkongolo, K. K. (2013). Assessing the Effects of Integrated Soil Fertility Management on Biological Efficiency and Economic Advantages of Intercropped Maize (Zea mays L.) and Soybean (Glycine max L.) in DR Congo. Am J Exp Agric, 3(3), 520-541. https://doi.org/ 10.9734/AJEA/2013/2628

Nalivata, P., Kibunja, C., Mutegi, J., Tetteh, F., Tarfa, B., Dicko, M. K., ... Wortmann, C. S. (2017). Integrated soil fertility management in Sub-Saharan Africa. In C. S. Wortmann, K. Sones (Eds.), Fertilizer use optimization in Sub-Saharan (pp. 25-39). Nairobi: CAB International.

Nelson, D. W., \& Sommers, L. E. (1982). Total carbon, organic carbon and organic matter. In A. L. Page, R. H. Miller, \& D. R. Keeney (Eds.), Methods of soil analysis, Part 2: Chemical and biological Properties (2nd ed., pp. 199-224). Madison: Am Soc Agron. https://doi.org/10.2134/agronmonogr9.2.2ed

Nyamangara, J., Mtambanengwe, F., \& Musvoto, C. (2009). Carbon and Nitrogen Mineralization from Selected Organic Resources Available to Smallholder Farmers for Soil Fertility Improvement in Zimbabwe. Afr $J$ Agric Res, 4(9), 870-877. https://doi.org/10.5897/AJAR

Nyamangara, J., Piha, I. M., \& Giller, K. E. (2003). Effect of Combined Cattle Manure and Mineral Nitrogen on Maize N-uptake and Grain Yield. Afr Crop Sci J, 11(4), 289-300. https://doi.org/10.4314/acsj.v11i4.27579

Okalebo, J. R., Gathua, K. W., \& Woomer, P. L. (2002). Laboratory methods for soil and plant analysis: A working manual (2nd ed.). Nairobi: TSB-CIAT and SACRED Africa.

Oluwaranti, A., Fakorede, M. A. B., \& Badu-Apraku, B. (2008). Grain Yield of Maize Varieties of Different Maturity Groups under Marginal Rainfall Conditions. J Agric Sci, 53(3), 183-191. https://doi.org/ 10.2298/JAS08031830 
Onduru, D., Zake, J., Ebanyat, P., \& Ergano, K. (2002). Participatory On-farm Comparative Assessment of Organic and Conventional Farmers Practices in Kenya. Biol Agric Hort, 19, 295-314. https://doi.org/ $10.1080 / 1448765.2002 .9754935$

Palm, C. A., Gachengo, C. N., Delve, R. J., Cadisch, G., \& Giller, K. E. (2000). Organic Inputs for Soil Fertility Management in Tropical Agroecosystems: Application of an Organic resource database. Agric Ecosyst Environ, 83, 27-42. https://doi.org/10.1016/S0167-8809(00)00267-X

Place, F., Barrett, C. B., Freeman, H. A., Ramisch, J. J., \& Vanlauwe, B. (2003). Prospects for Integrated Soil Fertility Management using Organic and Inorganic Inputs: Evidence from Smallholder African Agricultural Systems. Food Policy, 28, 365-378. https://doi.org/10.1016/j.foodpol.2003.08.009

Rakhsh, F., Golchin, A., Agha, A. B. A., \& Alandari, P. (2007). Effects of Exchangeable Cations, Mineralogy and Clay Content on the Mineralization of Plant Residue Carbon. Geoderma, 307, 150-158. https://doi.org/ 10.1016/j.geoderma.2017.07.010

Roobroeck, D., Van Asten, P., Jama, B., Harawa, R., \& Vanlauwe, B. (2015). Integrated soil fertility management: Contributions of framework and practices to climate-smart griculture. Global Alliance for Climate-Smart Agriculture. https://doi.org/10.13140/RG.2.1.1695.2400

Rusinamhodzi, L., Corbeels, M., Zingore, S., Nyamangara, J., \& Giller, K. E. (2013). Pushing the Envelope? Maize Production Intensification and the Role of Cattle Manure in Recovery of Degraded Soils in Smallholder Farming Areas of Zimbabwe. Field Crops Res, 147, 40-53. https://doi.org/10.1016/ j.fcr.2013.03.014

Rustad, L. E., Campbell, J. L., Marion, J. M., Norby, R. J., Mitchell, M. J., Hartley, A. E., ... Gurevitch, J. (2001). A Meta-analysis of the Response of Soil Respiration, Net Nitrogen Mineralization, and Above-ground Plant Growth to Experimental Ecosystem Warming. Oecologia, 126, 543-562. https://doi.org/10.1007/ s004420000544

Samuel, A. L., \& Ebenezer, A. O. (2014). Mineralization Rates of Soil Forms of Nitrogen, Phosphorus and Potassium as Affected by Organomineral Fertilizer in Sandy Loam. Adv. Agric., 2014, Article ID: 149209. https://doi.org/10.1155/2014/149209

Schumacher, B. A. (2002). Methods for the determination of total organic carbon (TOC) in soils and sediments. US Environmental Protection Agency, Washington.

Six, J., \& Jastrow, J. D. (2002). Organic matter turnover. In R. Lal (Ed.), Encyclopedia of soil science (pp. 936-942). New York, Marcel Dekker. https://doi.org/10.1016/s0016-7061(03)00067-3

Stanford, G., \& Smith, S. J. (1972). Nitrogen Mineralization Potentials of Soils. Soil Sci. Soc. Am., 36, 465-472. https://doi.org/10.2136/sssaj1972.03615995003600030029x

Tilman, D., Cassman, K. G., Matson, P. A., Naylor, R., \& Polasky, S. (2002). Agricultural Sustainability and Intensive Production Practices. Nature, 418(8), 671-677. https://doi.org/10.1038/nature01014

Veldkamp, W. J. (1987). Soils of Zambia. Soil Bulletin No. 13 (2nd ed.). Lusaka: Soil Survey Unit-Research Branch, Department of Agriculture.

Waswa, B. N., Mugendi, D. N., Vanlauwe, B., Nandwa, S., \& Kung'u, J. (2003). Soil properties as influenced by different organic residue amendments in selected experiments in Kenya. African Crop Science Conference Proceedings, 6, 448-453.

\section{Copyrights}

Copyright for this article is retained by the author(s), with first publication rights granted to the journal.

This is an open-access article distributed under the terms and conditions of the Creative Commons Attribution license (http://creativecommons.org/licenses/by/4.0/). 